\title{
ARABSKI PROSTOR V GEOPOLITIČNI PERSPEKTIVI
}

\author{
dr. Jernej Zupančič \\ Oddelek za geografijo, Filozofska fakulteta Univerze v Ljubljani \\ Aškerčeva 2, SI-1000 Ljubljana \\ e-mail: jernej.zupancic@ff.uni-lj.si
}

Izvirni znanstveni članek

COBISS 1.01

\section{Izvleček}

Prispevek analizira geopolitično dinamiko arabskega prostora. Na podlagi strukturne analize družbenih, političnih, kulturnih in prostorskih sprememb so opredeljeni ključni problemi tega in širšega strateškega zaledja. Najobsežnejši 'pas črepinj' na svetu doživlja krize tako zaradi lastnih strukturnih sprememb kakor zaradi zunanjih pritiskov. Teh ne predstavlja le zahodna vojaška in tehnološka sila, temveč v vse večji meri konkurenca azijskih držav. V perspektivi se kažejo obrisi uvajanja novih (predvsem azijskih) sil v tem prostoru.

Ključne besede: arabski prostor, politična geografija, geopolitika, krizna območja, narodno vprašanje

\section{ARAB SPACE IN THE GEOPOLITICAL PERSPECTIVE}

\begin{abstract}
The paper is analysing the geopolitical structure and dynamics of Arab space. Based on structural analysis of social, political, cultural and spatial changes the key-problems and geopolitical features are recognized. Arab space is - more or less - the largest 'shatter belt' known by contemporary crises and similar processes in the near past. These are caused by inner and, even more, by outer geopolitical factors in the large regional surrounding. The western economic and military forces are perhaps loosing the role of key-factor in the area. In the near future, Asiatic powers might play a dominant role.
\end{abstract}

Key words: Arab space, political geography, geopolitics, crisis areas, ethnic studies 


\section{I.UVOD - ENO OD SVETOVNIH JEDER ALI SVETOVNA PERIFERIJA?}

Od Cohenovih razprav o politični regionalizaciji sveta (Parker, 1997, str. 207-208; Cohen, Middleton, 1967) od srede šestdesetih let dalje velja t.i. 'arabski svet' za utrjen geografski pojem. Do konca dekolonizacije je bil najobsežnejši pas puščav v senci rastoče blokovske polarizacije 'prazen' prostor, ki so ga obvladovale svetovne pomorske sile. V naslednjih desetletjih se je pomen tricelinskega spoja (Afrike, Azije in Evrope) v vzhodnem Sredozemlju in njegovem kopenskem zaledju nenehno stopnjeval. Po padcu blokovske delitve sveta je islamski arabski svet postal predmet nove ideološke percepcije. Na tem mestu velja spomniti na silovite polemike, ki jih je sprožilo Huntingtonovo delo Clash of civilizations (1996), v katerem avtor kot novo idejno 'jedro' izpostavi bojeviti islam. To morda ni naključje, saj je bil to čas uveljavljanja novega svetovnega političnega reda, v katerem je sprva odločno prevladovala 'zahodna' vojaško-politična sila. Toda prav ta svetovni politični red se je lomil ob neuspešnih poskusih pomiritve arabsko-izraelskega spora v Palestini in utrjeval v skupnih akcijah zoper domnevno največje ogroževalce svetovnega miru ter v skupnem nastopanju proti novemu sovražniku: globalnemu terorizmu na islamskih fundamentalističnih temeljih. Zoper tega so se v svojih strateških iskanjih usmerile zahodne demokracije, potem ko so se razrešile bremena ideološko-gospodarsko-vojaškega tekmovanja izza hladne vojne. Iran, Irak, Afganistan in nazadnje Libija so etape v poskusih vplivanja na domnevno jedro 'osi zla'.

Leta 2011 je vrsto arabskih držav v Severni Afriki in Jugozahodni Aziji zajel val množičnih demonstracij proti domačim diktaturam. Silovitost tega procesa in njegova geografska razširjenost sta podrla prepričanje o monolitnosti arabskih družb in njihovo domnevno protizahodno usmerjenost. Interpretacije vzrokov 'arabske pomladi' so precej različne, od tega da gre (zopet) za eno izmed 'uvoženih' revolucij pa do avtentičnih demokratičnih gibanj (Der neue Fischer Weltalmanach 2012, str. 10-14). Opozoriti je potrebno na podcenjevanje zlasti socialnih sprememb arabskih družb in bistveno spremenjene zunanje geopolitične okoliščine. Te spremembe močno vplivajo tudi na razmerja med dvema notranjima idejnima protagonistoma: panarabsko in panislamsko idejo.

Namen prispevka je osvetliti geopolitične dimenzije arabskega prostora. Pri tem se bomo podrobneje osredotočili na tri problemske sklope: strukturne značilnosti arabskih držav, njihov politično-teritorialni razvoj in sodobno geopolitično strukturo arabskega jedra ter nekoliko tudi njegove nemirne soseščine.

\section{POJEM IN STRUKTURA ARABSKEGA PROSTORA}

Arabski prostor ni enoten geografski pojem. Navadno ga povezujemo z razširjenostjo govorcev arabskega jezika, ki pa ima več različic. Dokaj uveljavljeno je pragmatično stališče, ki ta pojem enači s t.i. Arabsko ligo, zvezo držav arabskega govornega območja in islamske kulture. Po tem merilu je ozemlje precej večje od Evrope (nad 13 milijonov km²), medtem ko je število prebivalcev nekoliko manjše (dobrih 400 milijonov). V grobem je mogoče ta 
obsežni prostor med Atlantikom, Sredozemskim morjem, Perzijskim zalivom in Indijskim oceanom razdeliti na tri velike enote: države Magreba $^{1}$ na zahodu, Mašrika ${ }^{2}$ na vzhodu in doline Nila v srednjem delu. Skoraj v središču tega območja se nahaja Palestina, ki jo poleg 'arabskih' pokrajin sestavlja še judovska država Izrael. Arabski ligi pripadajo tudi Džibuti in Somalija na afriškem rogu in Komori v Indijskem oceanu.

Arabski svet je spoj Azije in Afrike, ki se vleče v pasu sklenjenih subtropskih polpuščav in puščav. Posamezna gorstva (Atlas, Libanon, Omansko gorovje in na jugu Jemensko višavje, Asir in Hadramut) omogočajo nekaj več namočenosti in s tem priložnosti za kmetijstvo. Sicer pa je ta obširni predel odvisen bodisi od alogene vode s severa (Evfrat in Tigris imata povirje visoko v Armenskem višavju in Vzhodni Anatoliji), bodisi z juga (povirje Nila je v Etiopskem ter v Vzhodnoafriškem višavju, precej vodnati so tudi pritoki z juga Sudana). Ta okoliščina je nekoč v zgodovini omogočila razvoj prvih velikih poljedelskih civilizacij, danes pa je izrazito omejevalna. Pomanjkanje vode postaja glavni gospodarski problem, ki ga z energenti bogate države rešujejo z umetnimi postopki pridobivanja pitne vode iz morske. Velik del površja je povsem brezvoden, le redke oaze nudijo naravne možnosti preživetja. Območje je zelo neenakomerno gosto naseljeno z večjimi zgostitvami v dolini ter delti Nila, v osrednjem delu Mezopotamske nižine, v jugozahodni Arabiji (t.i. Srečna Arabija), v predelih ob vzhodnem Levantu (Sirija in Libanon) ter širšem predelu Atlasa na zahodu. Na podlagi črpanja nafte in zemeljskega plina so nastala naseljena območja tudi v notranjosti, predvsem v širši obalni coni ob Arabskem (Perzijskem) zalivu. Tam so vzorčni primeri izrazito 'umetnega' sveta, saj so v zadnjih desetletjih zgradili ne le velike mestne aglomeracije, temveč poskrbeli tudi za ozelenjevanje te pokrajine. Te družbe so ekološko zelo ranljive, saj morajo že dobršen del vode pridobivati, transportirati na dolge razdalje in prečiščevati. Prav tako so prehransko odvisne, saj imajo razen Egipta in Iraka vse države preskromne proizvodne možnosti in so vezane na uvoz hrane.

Celotno območje je po naselbinski tradiciji kontinentalno v Mašriku in maritimno $\mathrm{v}$ Magrebu. V slednjem obsega poselitev predvsem širše obalne predele ob Sredozemskem morju, mnogo manj pa ob Atlantskem oceanu. Vezana je predvsem na tradicionalne in moderne oblike kmetijstva mediteranskega tipa. Ribištvo in druge oblike izkoriščanja morskega bogastva v vodi in na kopnem (solinarstvo, turizem, namakalno poljedelstvo) so dobrodošli viri preživetja. V Mašriku je drugače, saj so nekoliko gostejša naselitvena jedra nastala šele v novejšem času praktično povsem na novo. Omogočilo jih je črpanje energentov na obali ter v šelfu Arabskega zaliva, precej tudi v notranjosti. V širšem obalnem pasu tega morja se je oblikovala povsem nova ekumena, ki jo omogoča in vzdržuje izredno energetsko bogastvo. Toda nič manj pomembna ni možnost, da iz slane morske vode z razsoljevanjem pridobivajo pitno, tehnološko in komunalno vodo. Za nekatere arabske države je pomembna gospodarska panoga tudi turizem, saj so zaradi izjemne kulturnozgodovinske dediščine priljubljen cilj mnogih evropskih in vse bolj tudi azijskih turistov. Izjemen pomen imajo tudi veliki morski prelivi (Gibraltar, Bab al Mandab, Hormuška ožina) in Sueški prekop, predvsem

\footnotetext{
1 Izraz 'magreb' pomeni v arabščini 'zahod'. Navadno v ta krog prištevamo Atlaške države (Maroko, Alžirija, Tunizija), Libijo, Mavretanijo in Zahodno Saharo.

2 Izraz 'mašrik' pomeni v arabskem jeziku 'vzhod'. Vanj so vključene države Arabskega polotoka do Mezopotamije in Sirije ter seveda brez Izraela.
} 
zaradi nenehnega povečevanja prometa različnih dobrin med Azijo in Evropo. Povečevanje prometa in še posebej prometa z energenti pa predstavlja po drugi strani ekološko grožnjo, kar utegne dolgoročno ogrožati uporabo vode za razsoljevanje, ribištvo in turizem.

Arabski svet razpolaga z izjemnim naravnim bogastvom, ki pa ni le v zalogah nafte in zemeljskega plina. Največ nafte načrpajo v Saudovi Arabiji, sledijo Združeni arabski emirati, Kuvajt, Irak, Alžirija, Libija in Egipt. Obilje nekaterih rudnin (na primer železove rude v Mavretaniji in Zahodni Sahari, Siriji, Egiptu in Saudovi Arabiji, svinec in cink v atlaških deželah, fosfati v Maroku, Zahodni Sahari, Tuniziji in Jordaniji) daje dolgoročno dobre možnosti za razvoj industrijskih panog ali v slabšem primeru surovine za izvoz. Dolgoročno je pomemben energent lahko tudi izkoriščanje sončne energije, za kar ima opisani predel spričo geografske lege izjemno ugodne pogoje.

Arabski svet leži v sredini obširnega območja držav s prevlado islamske veroizpovedi. Muslimanov je danes dobro milijardo in pol in predstavljajo najhitreje naraščajočo versko skupino na svetu. Arabski prostor predstavlja torej približno četrtino muslimanskega sveta. Na severu je obkrožen s pasom močnih držav, Turčije, Irana in Pakistana (skupaj okrog 360 milijonov prebivalcev). Severno od tod sledi pas manjših in šibkejših držav od Balkanskega polotoka (Bosna in Hercegovina, Kosovo, Albanija), prek Kavkaza (republike v Rusiji, Azerbajdžan) do Srednje Azije (Turkmenistan, Uzbekistan, Kirgizija, Kazahstan) in sega potem še na območje zahodnokitajskih provinc. V ta regionalni okvir se uvršča tudi Afganistan. Skupaj štejejo okrog 130 milijonov pripadnikov in so regionalna večina. Na območju Jugovzhodne Azije so še štiri pretežno muslimanske države: Bangladeš na Indijski podcelini ter Indonezija, Brunej in Malezija. Muslimanske skupnosti so regionalno močno prisotne tudi v nekaterih sosednjih državah (Mjanmar, Tajska, Filipini).

Južno od Sahare sledi pas držav, kjer prihaja do srečanja in prepletanja ter še pogosteje do konfliktov, prav posebno zaradi očitnih medverskih razlik in vztrajnih poskusov uveljavljanja političnega islama. Od Senegala in Gambije najbolj na zahodu prek pretežno muslimanskih predelov Malija, Burkine Faso, Nigra in Čada ter severne Nigerije se razprostira obsežno območje kontinuirane poselitve muslimanskega prebivalstva (nad 200 milijonov), ki pa je po jeziku in postkolonialni dediščini zelo različno. Ta pas je prizorišče številnih spopadov in kriznih žarišč. Opravka imamo tako z mladimi nacionalizmi prebujajočih se afriških narodov, kakor tudi z velikim vplivom verske pripadnosti. Pretežno muslimanski sever proti krščansko-animističnemu jugu je trdoživa podoba območja, ki dobiva sedaj podobno geopolitično strukturo kot prej omenjeni severni pas muslimanskega sveta. Tu je več poskusov regionalnih avtonomij in tudi oblikovanja novih držav. Zadnja med njimi je Južni Sudan, ki ga je mednarodna skupnost sprejela, noče pa podobnega primera pri Somalilandu (na območju nekdanje Britanske Somalije). Pozornost zbuja tudi naraščanje deleža muslimanskega prebivalstva v Etiopiji, sicer doslej pretežno s krščansko - koptsko veroizpovedjo.

Države arabskega prostora kljub domnevno enotni jezikovni in verski strukturi prebivalstva niso enotne. Precejšnje razlike so že med bližnjimi državami, tako da je notranji ustroj arabskega sveta, ki ga politično povezuje Arabska liga, dokaj zapleten.

Še najbolj homogena je Mavretanija, ki v večjem delu obsega območje Sahare; le na jugozahodu prehaja v polpuščavo. Obširna in ravna po naravi, toda raznolika po prebivalstveni 
sestavi. Večino (okrog 80 \%) predstavljajo beli Arabci in Berberi, ostalo petino pa črnska ljudstva (Volofi, Fulani, Sarakoli in drugi). Verska enotnost ne predstavlja pomembnejše družbene vezi, saj je zaradi tradicionalne socialno-kulturne polarizacije večkrat prišlo do notranjih sporov in nastopov proti črni manjšini.

Še več posebnosti izraža Maroko, ki skupaj z anektiranim ozemlje Zahodne Sahare predstavlja najbolj maritimno arabsko silo. Edina izmed magrebskih držav se je obdržala kot ustavna monarhija in tudi ljudski upori v letu 2011 je niso prizadeli. Razmerje med Arabci $(60 \%)$ in Berberi (40 \%) se nagiba v korist prvim tudi zaradi prevlade arabščine v javni sferi in tudi načrtnih prizadevanj. Toda kultura je še močno berberska in ima ob tem močno socialno konotacijo. Maroko je država z velikimi medregionalnimi razlikami.

Sosednja Alžirija ima podobno razmerje med arabskim in berberskim prebivalstvom (70 : 30), le da je nekdanja francoska kolonialna uprava pustila drugačno dediščino. Obalni predeli Alžirije so doživeli razmeroma močno francosko agrarno in industrijsko kolonizacijo, ki pa se je morala po osvobodilni vojni (1954-1962) skoraj v celoti umakniti. Poskusi poenotenja - arabizacije Berberov in Tuaregov niso uspeli, sprožili pa so precej sporov. Alžirija je primer izrazito asimetrične države: skoraj 80 \% ozemlja leži v saharskem predelu, ki pa razpolaga z veliko večino nafte in zemeljskega plina, demografsko jedro pa je v ožjem obalnem pasu. Država ima skromne zaloge sladke vode in je prehransko odvisna od uvoza.

Tunizija je jezikovno skoraj homogena (arabska), gospodarsko pa bolj uravnotežena, saj v severnem mediteranskem delu uspeva raznolika kmetijska proizvodnja, zelo pomembni so turizem ter izkoriščanje naftnih in plinskih polj in ležišč fosfatov. Libija je versko in etnično precej homogena (arabizirani Berberi) in prav tako fizičnogeografsko; več kot 90 \% površja so puščave. A to ni razvojna prednost države z dolgo obalno črto in skromnimi gospodarskimi učinki na ta račun. Vzroke mnogih libijskih težav gre iskati v posebnostih njenega političnega in gospodarskega razvoja (Lacoste, 2009, str. 236-240).

Egipt je demografsko najmočnejša država arabskega sveta z izborno geografsko lego med dvema celinama. Zahodni del sestavlja Libijska puščava, vzhodnega pa precej višja Arabska puščava; ta predel se potem strmo spušča k obalam Rdečega morja. Med tema dvema območjema sta dolina in delta reke Nil, območje največje agrarne zgostitve v Afriki in Jugozahodni Aziji. Med 82 milijoni prebivalcev jih večina govori arabsko, a po identiteti je mogoče razlikovati več skupin. Poleg večinskih Arabcev (okrog 80 \%) je še vsaj $15 \%$ krščanskih Koptov - Egipčanov, pa manjšine Nubijcev, Kordofanov in drugih. Egipt je zaradi izrazito neenakomerne gostote poselitve in primanjkljaja tako plodne zemlje kakor vodnih virov geografsko občutljiva država.

Na prvi pogled ima južna soseda Sudan podobno strukturo. Vendar je že glede vodnih virov bistveno na boljšem, saj so vodotoki na jugu veliko bolj izdatni in tudi podnebje je proti jugu že nekoliko bolj namočeno. Predvsem pa lahko izkorišča prednosti vodnega bogastva Nila. Sudan je etnično izjemno raznolik, saj poleg arabiziranih Nubijcev pomemben del predstavljajo tudi sudanska ljudstva kot so Furi, Nube, Barijci, Bedži in drugi. Po novejših raziskavah razpolaga Sudan z izdatnim naftnim bogastvom, pa tudi z mnogimi rudami, a jih zaenkrat le skromno izkorišča (Held, Cummings, 2011, str. 520-529). 
Arabski polotok je zgodovinsko izhodišče arabskega sveta. Večino uravnanega površja, ki se zložno spušča proti plitvemu Arabskemu zalivu, pokrivajo puščave. Edino jugozahodni del (Asir, Jemen in Hadramaut) je višji ter namočen, zato tudi z gostejšo agrarno naselitvijo. V antiki je ta del veljal za 'Arabio Felix'3. Podobna agrarna kulturna pokrajina se je razvila na vzhodnem vznožju Omanskega gorovja. Na severu ga obroblja Mezopotamija, ki se prek Sirije vije proti Palestini: to je območje t.i. 'rodovitnega polmeseca', s katerim se arabski svet zaključi. Politično jedro je Saudova Arabija, ki jo na severu obroblja niz naftno bogatih šejkatov (Kuvajt, Bahrajn, Katar, Združeni arabski emirati) ter Oman, na jugu pa demografski ekvivalent Jemen. Od Palestine jo loči Jordanija, medtem ko poteka meja z Irakom po uravnanem in nenaseljenem puščavskem svetu.

Po strukturi prebivalstva in gospodarski usmerjenosti se države Arabskega polotoka močno razlikujejo med seboj. Razen Jemna, ki je republika, so po ureditvi vse kraljevine (šejkati). Šejkati ob Arabskem zalivu imajo izrazito gospodarsko monostrukturo, saj večino dohodkov prinaša črpanje nafte in zemeljskega plina ter predelava nafte. Ostalo so različne servisne dejavnosti, ki jih večidel opravljajo tujci. Teh je v skoraj vseh omenjenih državah najmanj četrtina, največ v Kuvajtu (dobrih $60 \%$ ). Med njimi prevladujejo državljani islamskih držav (Irana, Pakistana, Bangladeša, Indonezije), pa tudi Indije in Filipinov (Held, Cummings, 2011, str. 440-444). Oman je dalj časa zaostajal za bogatimi emirati, v zadnjih dveh desetletjih pa je po zaslugi bogatih zalog zemeljskega plina postal po strukturi zelo podoben svojim zahodnim sosedam. Povsem drugačen pa je Jemen, ki sodi med najrevnejše države na svetu, kar ni le odraz skromnejših energetskih virov in rud, temveč tudi posebnosti zgodovinskega razvoja. Je edina izrazito emigracijska država, kjer pa zaradi visokega naravnega prirastka število prebivalcev zelo naglo narašča. Jemenci imajo različen izvor, saj se čutijo vplivi tako iz Afrike kakor Indije in različnih skupin z Arabskega polotoka. Jezik je enoten - arabski, vendar v veliko lokalnih različicah. V verski sestavi rahlo prevladujejo suniti (nad $57 \%$ ), veliko je šiitov, zlasti pripadnikov ločine zaiditov ( $42 \%$; Held, Cummings, 2011, str. 493), precej je tudi vahabitov. Jemen predstavlja s svojo gospodarsko strukturo arabski pol revščine in je $\mathrm{v}$ ostrem nasprotju z mnogo bogatejšimi kraljevinami drugod na polotoku.

Irak je posebnost med vsemi arabskimi državami. Reliefno je odprt na tri strani, le proti Iranu in Turčiji na severovzhodu meji na gorati svet Zagrosa. Država je skoraj celinsko zaprta, saj ima dostop do morja le po Šat el Arabu. Obširno Mezopotamsko nižino namakata Evfrat in Tigris in je bil, podobno kot dolina spodnjega Nila, prizorišče zelo stare civilizacije, ki jo je pozneje prekrila arabska z islamizacijo ter za njo turška. Irak je podobno kot sosednja Sirija, Iran in dalje Afganistan ter Pakistan etnično izrazito mešan: okrog $75 \%$ je Arabcev, $20 \%$ Kurdov in še nekaj drugih skupnosti. Razdeljen je tudi versko. Sunitskemu islamu pripadajo skoraj tri četrtine prebivalstva, šiitov je tretjina, nekaj pa je še drugih skupnosti, od razseljenih Judov in Armencev do različnih beguncev in delavcev. Območje Sirije in Iraka je v bližnji preteklosti zaradi svoje moči predstavljalo eno od jeder arabskega prostora, a je danes povsem nazadovalo (Lacoste, 2009, str. 241-245). Irak je bil

3 Pogosto jo prevajajo kot 'srečno Arabijo'. Gre bolj za pomen 'rodovitna'; ugodne razmere za kmetijstvo so v dobi vzpona velikih poljedelskih kultur v dolini Nila in 'rodovitnem polmesecu' pomenile tudi 'srečo'. 
dvakrat tarča zavezniških napadov, sedaj je pod mednarodnim varstvom. Obilje zalog nafte in zemeljskega plina je omogočilo razvoj, toda dolgotrajno stanje vojn in mednarodne intervencije so Irak osiromašili. Sosednja Sirija zaseda del Levantske obale in planotasto površje srednje Sirije, kjer se na jugu končuje predel 'rodovitnega polmeseca'.

\section{POLITIČNO-TERITORIALNI RAZVOJARABSKEGA PROSTORA}

V kratki pregledni analizi politično-teritorialnega razvoja držav arabske kulturne provenience se omejujemo predvsem na tiste faze, ki so bodisi posredno bodisi neposredno vplivale na oblikovanje današnjih arabskih držav, prispevale k določeni narodni in verski razporeditvi prebivalstva ali pa z oblikovanjem določenih razmerij med skupinami ustvarjale podlago za poznejše konflikte.

Pojem 'države' je nastal prav na območjih ob srednjem in spodnjem toku Nila ter ob Evfratu in Tigrisu v Mezopotamiji. Ta začetek civilizacij so omogočile okoliščine, da se je v sicer suhi pokrajini zaradi obilja alogene vode, ki je plavila tudi rodovitno blato, oblikovala državna organizacija. Bila je odvisna od rek, še bolj pa od lastne iznajdljivosti. Stari Egipt in države na prostoru Mezopotamije nekateri radi imenujejo kar 'hidravlične' civilizacije $\mathrm{e}^{4}$, poudarjajoč pri tem pomen čvrstega hierarhičnega družbenega ustroja (Seton-Watson, 1980, str. 231). Toda dobrih 3500 trajajoča egipčanska (od 4. tisočletja do 30 pr. n. š.; Veliki slovenski leksikon, 2007, str. 478) in mezopotamska civilizacija (od 4. tisočletja do 539 pr. n. š.; Veliki slovenski leksikon, 2007, str. 137) sta po zavzetju počasi zatonili v pozabo. V širokem južnosredozemskem loku, ki je povezoval večino takrat 'civiliziranega' sveta, so se javljale nove države, od Feničanov, Hebrejcev in Kartažanov, na severnem pa nekoliko pozneje antična Grčija ter predvsem Rim. Na ta prostor so pomembno vplivale sile s severa (Hetiti, Medijci, Parti in Perzijci, pozneje tudi Urartu), z juga pa plemena, ki so naseljevala jugozahodni del Arabskega polotoka.

Grški vzpon je razrahljal največjo vojaško moč tistega časa - Perzijo, kar je po vzponu rimskega imperija gotovo olajšalo osvajanje številnih, vendar šibkih držav v celotnem Vzhodnem Sredozemlju in v njegovem kopenskem zaledju. Z rimsko veledržavo se je jedro moči iz afro-azijskega kopenskega stika prestavilo v Južno Evropo. Ni pa jim uspelo načeti močnih držav na območju današnjega Irana. Perzija se je vse do arabske invazije v 8. st. zadržala kot najmočnejši regionalni dejavnik (The Times atlas svetovne zgodovine, 1989, str. 78). Hiranje Rima in oblikovanje manjših držav je zanesljivo olajšalo pot novi sili - islamu - ki se je leta 610 pojavil kot versko gibanje, se po hidžri ${ }^{5}$ leta 622 utrdil in po Mohamedovi smrti razmeroma hitro postal dominantna politična sila (The Times atlas svetovne zgodovine, 1989, str. 104-105). V dobrem stoletju se je islam z arabskimi vojaškimi osvajanji razširil po širokem prostoru med Iberskim polotokom na zahodu in pokrajino Sind v Indiji.

\footnotetext{
4 Države, ki so temeljile na organiziranih sistemih namakanja in kultivacije zemljišč.

5 Beg Mohameda s privrženci iz Meke v Medino; tam se je s pridobitvijo mnogih pristašev gibanje okrepilo in vrnilo 632 v Meko.
} 
Po Houraniju (1991) je bilo za širjenje nove vere bolj kot bojeviti fanatizem zaslužno njegovo usidranje v vladajočih slojih ter šibkost nasprotnikov. Islam je politično in vojaško nastopil v času, ko so bile države v soseščini oslabljene. Ob islamu se je širila tudi arabščina, ki je bila 'jezik knjige' in je prek verskih besedil simbolizirala enotnost. Arabščina je v kratkem času postala lingua franca prostora med Atlantikom in Indijskim oceanom, čeprav so bili njegovi nosilci odločno $\mathrm{v}$ manjšini in čeprav je v vzporedni javni rabi še obstajal drug (domači) jezik. Tako so se arabizirali Berberi v dobršnem delu Magreba, prebivalci Egipta in prebivalci skoraj celotnega 'rodovitnega polmeseca'. Osvojitev in islamizacija ter arabizacija teh predelov je izjemno povečala gospodarsko moč in okrepila tudi vojaško silo arabsko-islamskega prodora (Hourani, 1991, str. 21-27). Na tem prostoru dominirata arabščina in islam še danes; prvi določa arabski prostor, ki je politično in simbolno jedro širšega islamskega sveta.

Islam je bil do drugih verovanj večinoma toleranten. Vendar velja preprosto dejstvo, da se niso arabizirali tisti, ki se niso islamizirali. Tako so ostale številčne judovske, armenske, grške in koptske kolonije tudi še v naslednjih stoletjih. Drugi pojav znotraj islamskega sveta pa je bila cepitev na več vej. Danes sicer prevladujejo suniti, šiitov je zdaleč največ predvsem v južnem Iraku in Iranu. Ob nastajanju novih ločin ni prihajalo do spopadov; islamski svet pravih medverskih vojn dejansko ni poznal (Hourani, 1991, str. 96-97), je pa postal toliko bojevitejši do 'nevernikov', predvsem kristjanov. Ločine so lažje uspevale v pogojih izolacije, kakršne je nudil gorati in veliko bolj gostoljubni predel na jugozahodu Arabskega polotoka ter med nomadi. Sunitizem se je močno širil zlasti po mestih, kar je po nekaterih prepričanjih močno olajšalo širjenje islama v celoti. Zaradi delitve na kalifate je bil arabski prostor tedaj obširen, toda neenoten.

Na zahodu je prodor islama zaustavila rastoča sila - Frankovska država (bitka pri Poitiersu, 732). Šele več stoletij pozneje (1492) je španska reconquista uspela izriniti Mavre z Iberskega polotoka. Vojaški pohodi t.i. križarskih vojn se politično niso posrečili, a so močno razrahljali sicer ne preveč čvrste moči kalifatov v vzhodnem Sredozemlju. Oblikovali so tudi niz fevdalnih državic, za katerimi so tudi po porazu in dokončnem izgonu iz Palestine (1291, Akra) ostale krščanske kolonije (Held, Cummings, 2011, str. 79). Toda ta čas je veliko bolj pomemben zaradi nastopa nove sile - Turkov. Iz srednjeazijskega prostora izvirajoča ljudstva so s prihodom v Malo Azijo in z uspešnimi vojnami proti Bizantinskemu cesarstvu naglo pridobivala politično moč. Sprejem islama je verjetno olajšal izgradnjo družbene hierarhije. Po Osmanu I. so jih kasneje imenovali Osmani, država pa osmanska država oziroma imperij, ki je teritorialno različno obstajal polnih 624 let (1299-1923; Kostova, Despotova, 2003, str. 10-12; str. 117). Sultan Osman I. je izkoristil šibkost številnih malih kalifatov in nemoč Bizanca ter pričel oblikovati dominantno silo Orienta za naslednjih nekaj stoletij. $\mathrm{S}$ tem je bilo arabske ere konec, zadržala pa se je arabska kultura, jezik in pismenstvo, in sicer ob arabščini kot jeziku verskih besedil. Ko je Konstantinopel postal Istanbul in se je s turškimi osvajanji evropske kopnine jedro države prestavilo med Črno in Egejsko morje, je obširen 'arabski' svet postajal vse bolj periferen. Otomani so osvojili večino teh dežel in vzpostavili vazalne odnose. Turčija je tako v 17. st. dosegla svoj največji teritorialni obseg in tudi gospodarsko moč (Kennedy, 2002, str. 38-41). Na odvisnih ozemljih (npr. Magreb, 
Egipt, Sudan) so se nadaljevale prakse upravljanja še izza prejšnjih kalifatov, kar je utrjevalo regionalne identitete - podlago današnjih držav. Pri tem je treba posebej podčrtati, da je bilo ozemlje z določeno obliko vladanja pod vladarji - vazali Visoke Porte - relativno samostojno. Toda turške oblasti niso radi sprejemali povsod in na območju današnje južne Arabije je bilo več uporov. Sledil je tudi gospodarski zastoj, še posebej ko je po 17. st. začela turška moč naglo pojemati. Verjetno je k temu pomembno pripomogla tudi raznolikost upravljanja ozemeljsko velikega, zelo raznolikega in po kulturno-gospodarski tradiciji izredno pisanega imperija.

Nadaljnji politično-teritorialni razvoj današnjega arabskega prostora so pričele bistveno določati predvsem evropske sile in sicer na dva načina: $\mathrm{z}$ ozemeljskim osvajanjem ter $\mathrm{z}$ idejami nacionalizma. $\mathrm{V}$ tem procesu so se namesto nekdanjih evropsko - turških rivalstev pojavile nove evropske sile Francija in Velika Britanija, ki sta že imeli svoje kolonije v Aziji, Afriki in Ameriki. Delno je v ta spopad za ozemlje vstopila tudi Španija, vendar v zelo omejenem obsegu: osvojila je predele današnjega Maroka in Zahodne Sahare. Franciji je že z napoleonskimi pohodi uspelo začasno osvojiti Egipt in obale Severne Afrike, a je kasneje lahko zadržala le Magreb (razen Maroka, ki je bil španski), pozneje pa je z osvojitvijo večjega dela Zahodne Afrike med Sredozemljem in Gvinejskim zalivom oblikovala največjo sklenjeno francosko kolonijo: Francosko Zahodno Afriko. V Alžiriji in Tuniziji so nastale močne agrarne francoske naselbine. Francija je 1861 postala tudi zaščitnica kristjanov v današnjem Libanonu (maronitov), kar je pozneje, po prvi svetovni vojni, vodilo do oblikovanja današnjih meja Libanona ${ }^{6}$ in prispevalo tudi k specifični ureditvi te države (Held, Cummings, 2011, str. 293). Leta 1859 so pričeli graditi Sueški prekop, ki je močno skrajšal poti med Evropo in Indijo ter ostalo Azijo. Angleške sile so se usmerile proti dolini Nila in s težavami osvojile Egipt in Sudan ter povezale to ozemlje s kolonijami v Vzhodni Afriki. Britanci so osvojili tudi oporne točke (npr. Aden, Britansko Somalijo, otok Sokotra). Za Tripolitanijo in Cirenajko (obalni deli današnje Libije) se je začela zanimati Italija in jo 1911 formalno in šele leta 1934 tudi dejansko obvladala. Sledila je močna italijanska kolonizacija. Po porazu v drugi svetovni vojni se je morala Italija s pariško pogodbo odpovedati Libiji, država pa se je v teh mejah osamosvojila leta 1951 (Napokoj, 2008, str. 47-48; Der Fischer Weltalmanach, Staatenlexikon, 2006).

Na turško-balkanske odnose je močno vplivala Rusija, ni pa vplivala neposredno na arabski prostor. Posredno pa je vendarle ruski kontekst zelo pomemben, saj je zaradi rastoče vojaške moči Rusija predstavljala regionalno silo in grožnjo. 'Zapreti Rusijo' proti jugu je bila prepoznana britanska geopolitična nuja že konec 19. st. (Parker, 1997, str. 96-99). Nasprotno je Nemčiji skladno z usvajanjem uporabnosti Haushoferjeve geopolitike ustrezalo ohranjanje močno oslabljenega otomanskega imperija, ker je s tem želela slabiti tako Rusijo (da ne bi dosegla neovirane pomorske moči ter prevelikega vpliva na Balkanu) kot Veliko Britanijo in z njuno slabitvijo zmanjševati njun vpliv v Srednji Evropi ter širše (Parker, 1997, str. 115).

Drugi vir slabitve turške moči so predstavljala nacionalistična gibanja različnih narodov znotraj otomanskega imperija. 19. st. je bilo čas vzpona ideje nacionalne države. Osamosvajati so se pričele robne cone: Balkan, Kavkaz, vzhodni Levant, Egipt in Magreb. Na

6 Libanon je pod francoskim protektoratom razglasil neodvisnost leta 1941. 
Balkanskem polotoku so začele nastajati nove države, od Grčije prek Črne gore in Srbije do Bolgarije in Romunije. Podobne ideje in načrte so imeli tudi Armenci (Balakian, 2003, str. 35-39), vendar jih je turška armada preprečila z množičnimi pogromi (1909) in potem še med prvo svetovno vojno. Genocid pod Araratom je zahteval 1.700 .000 armenskih žrtev $^{7}$ in za skoraj stoletje zamrznil odnose med Armenci in Turki (Balakian, 2003, str. 319-330). Za te dogodke so še danes zelo različne interpretacije, saj turški viri postavljajo veliko selitev tudi v luč stiske turške države, ki je tedaj naglo izgubljala ozemlje za ozemljem (Halacoglu, 2006, str. 79-80).

Obenem sta v tistem času nastopila še dva nacionalizma: turški in arabski. Medtem ko je prvi vodil k reformi in modernizaciji turške države ter obenem skušal zaradi geopolitičnih razlogov ohraniti teritorialne okvire imperija, je drugi težil k njegovi prekinitvi ter oblikovanju panarabske države. Nastop nacionalizmov je na prelomu iz 19. v 20. st. dokaj tipičen, saj so zelo sorodna gibanja rahljala še dve sosednji multietnični državi: rusko carstvo in habsburško monarhijo. Oba sta v prvi svetovni vojni doživela korenite spremembe in razpadla, na njunem političnem prizorišču pa so se oblikovale nadomestne države. Čeprav jih je pri tem vodila nacionalna ideja, so bile mnoge izmed njih le nekoliko manj večnarodne in večverske, kar je ohranjalo enega od poglavitnih problemov njihovega obstoja: nacionalno vprašanje.

Mladoturško revolucijo 1908 je zato treba gledati predvsem v luči vzpona turškega nacionalizma. Stanje so izrabile male balkanske države in nekoliko pozneje, v balkanskih vojnah 1912, turška ozemlja na Balkanu omejile na zaledje Carigrada. Avstro-Ogrska je anektirala Bosno in Hercegovino, Italija pa je v tem času zavzela ozemlja v današnji Libiji. Toda po drugi strani so bile reforme v Turčiji pomembne zaradi sprememb v turški upravi, vojski in družbi (Fraser, Mango, McNamara, 2011, str. 23-26). Turčija ni uspela zajeziti razkroja robnih delov svoje države, še posebej ne, potem ko je med prvo svetovno vojno 1916 prišlo tudi do arabske vstaje. Vendar je imel arabski nacionalizem mnogo manj možnosti za uspeh, saj so ga že na začetku krnile velike razlike med lokalnimi voditelji, medtem ko evropskim razmeram primerljivega meščanstva ni bilo. Poleg tega je bilo veliko tudi britanskih in francoskih vplivov, ki so v procesu razkroja otomanske periferije iskale priložnosti za širjenje svojih posesti in to večinoma tudi dosegle (Seton-Watson, 1980, str. 250). Arabski nacionalizem se je zato tesneje naslonil na arabski jezik in kulturo na eni in na islam na drugi strani: oba elementa srečujemo v valovanju (pan)arabskega nacionalizma praktično vse do danes. Medtem se je turška nacionalna ideja naslonila na moderni turški jezik, ki pa ga je bilo treba šele oblikovati. Jezikovna reforma je bila bistven del novih nacionalnih prizadevanj mladoturške revolucije. Pozneje je sledila turkizacija ozemelj z neturškim prebivalstvom (Fraser, Mango, McNamara, 2011, str. 7-9). Turčiji je po grško-turški vojni (1919-1922) uspelo ohraniti državo v današnjih okvirih, umakniti se je morala le z območja Kavkaza. Tako je mirovna pogodba v Sèvresu 1923 oblikovala današnje turške meje. S tem so bile zaključene tudi armenske in kurdske možnosti glede avtonomije oziroma samostojnosti (Fraser, Mango, McNamara, 2011, str. 197-202). Le na jugu je Turčija pozneje na račun Sirije pridobila še nekaj ozemlja pri Adani.

\footnotetext{
7 Po turških virih naj bi jih bilo veliko manj, okrog 400.000. Obstajajo tudi vmesne številke, od 600.000 do enega milijona ter milijona in pol (Balakian, 2003).
} 
Razkroj otomanske države je omogočil Franciji in zlasti Veliki Britaniji, zmagovalkama $\mathrm{v}$ prvi svetovni vojni, korenite posege $\mathrm{v}$ politično karto mediteranskega loka ter njegovega afriško-azijskega zaledja. Magreb je ostal francoski, Maroko španski, Libija italijanska in Egipt s Sudanom pod britanskim protektoratom. Logika protektoratov ni bila nikoli v zgodovini tako močno prisotna kakor na arabskem prostoru v prvi polovici 20. st. Sirija je pristala najprej pod francoskim varuštvom, Mezopotamija pod britanskim mandatom, prav tako tudi vse male države ob Arabskem zalivu. Vsaka od teh ima svojo zgodovino vstopa pod britansko zaščitništvo, ki se je uveljavljalo nekako od srede 19. st. dalje (Kuvajt 1899, Bahrajn 1861, Katar 1916, Združeni arabski emirati 1853 in Oman 1891). Tedaj oblikovane meje so, z zelo majhnimi spremembami, tudi današnje meje (Der Fischer Weltalmanach, Staatenlexikon, 2006).

Nekoliko drugačen je politično-teritorialni razvoj današnje Saudove Arabije, za katero je bilo značilnih več uporov proti otomanski nadoblasti že v 18. st., a so bili poraženi. Vodilna sila je bila vahabitska skupnost, ki se je od Turčije praktično ločila 1902 in trideset let pozneje razglasila kraljevino. Meje na zahodu je oblikovala predvsem Velika Britanija leta 1920 z mandatnim ozemljem današnje Jordanije, ki pa ga je 1922 razdelila na dva dela po dolini Jordana: na Palestino in Jordanijo. Povsem specifičen pa je bil razvoj današnjega Jemna, kjer so bili upori proti turški prevladi prav tako pogosti. Britanci so osvojili Aden z zaledjem, kar je vodilo do oblikovanja britanske kolonije, Južni Jemen pa je ostal protektorat. Severni Jemen je leta 1918 postal samostojna kraljevina, na jugu pa so se male državice šele 1959 združile v Južnojemensko federacijo (oba dela sta se združila 1990). Danes je Jemen praktično edina arabska republika z delujočim večstrankarskim sistemom. Žal to ne pripomore dosti h gospodarskemu vzponu in Jemen še vedno sodi med izrazito periferne države in družbe (Erhartič, 2009; Lacoste, 2009).

Po drugi svetovni vojni je bistveno novost v geopolitični realnosti arabskega sveta predstavljalo oblikovanje države Izrael. Poteza ima vsaj polstoletno zgodovino sionističnega gibanja, katere ključni politični cilj je bilo oblikovanje judovske države. Sam proces održavljanja ima tri ključne faze: pripravljalno, razglasitev in širjenje. Prva je trajala več desetletij, ko so sionisti z zbiranjem sredstev omogočili postopno kupovanje zemljišč v Palestini. Balfourjeva deklaracija leta 1917 in vzpostavitev britanskega protektorata sta stvari zelo olajšala, še posebej po delitvi mandatnega ozemlja na Palestino in Jordanijo leta 1922 (Fraser, Mango, McNamara, 2011, str. 103-132). Priseljenci so prihajali predvsem iz območja tedanje Sovjetske zveze, po letu 1933 tudi iz Tretjega rajha. Arabci so doseljevanju Judov ostro nasprotovali. Leta 1947 so Združeni narodi razglasili načrt delitve na judovski in arabski del, leto kasneje pa je Ben Gurion razglasil neodvisnost Izraela (Held, Cummings, 2011, str. 340-342). Sledile so izraelsko-arabske vojne, ki do danes bistveno krojijo podobo, strukturo in pomen predela, ki smo ga imenovali arabski prostor. Izrael je v njegovem središču, med dvema prebivalstveno najmočnejšima državama, Egiptom in Irakom. Oblikovanje Izraela in poznejše teritorialno širjenje je na njegovem obrobju ustvarilo niz ozemelj, ki imajo prehoden status: Golansko višavje (uradno del Sirije) je pod izraelsko vojaško zasedbo, Gaza se je oblikovala v eno najbolj gosto naseljenih begunskih območij, zahodni del Jordanije predstavlja teritorialni del palestinske države in na jugu Libanona so območja pod mednarodnim varstvom (Lacoste, 2009, str. 307-318). 
Oblikovanje Izraela ter prehajanje protektoratov v samostojne države in njihova medsebojna trenja pa niso edine geopolitične posledice v času po drugi svetovni vojni. Arabski prostor je postal zaradi naftnega bogastva izjemno privlačen za kapital zahodnih držav. Na prizorišče sta stopili novi sili. ZDA in Sovjetska zveza sta skupaj s svojimi blokovskimi zaveznicami pomembno kreirali notranjo politiko in gospodarski ter družbeni ustroj držav t.i. arabskega sveta. Nacionalizmi, naslonjeni bodisi na teritorialno-dinastično tradicijo na eni ter panarabske in panislamske ideje združevanja, so bolj kakor domači interesi ustrezali blokovskima voditeljicama pri oblikovanju ravnotežij med 'vzhodom' in 'zahodom'. V veliki meri so konflikti med državami in znotraj njih rezultat tega rivalstva in tipična posledica. Arabski svet je postal svetovni primer 'shatter belta' - 'pasu črepinj' (Parker, 1991, str. 7-9), znotraj katerega je obstajalo še nevralgično jedro - Izrael.

Sovjetski vpliv je vstopil v arabski svet z različnimi oblikami vojaške in tehnološke pomoči, ki so jo bile države voljne sprejeti. Osvobodilne vojne in njihove različice (državljanske vojne) so od magrebskih držav do Jemna in Sirije potrebovale pomoč. Obenem s sovjetsko pomočjo so prišli tudi poskusi sovjetizacije arabskih družb. Za vsaj določeno obdobje so jo uveljavili v Alžiriji (1965 do 1985), Tuniziji (1964 do 1980), Libiji (1970 do okrog 1990), Egiptu (1960 do sedemdesetih), Sudanu (1969 do osemdesetih), Jemnu (do uvedbe nekaterih prosovjetskih ukrepov je prišlo le v severnem delu, zaradi državljanske vojne niso uspeli), Siriji (1947 oblikovanje stranke Baas, od 1973 uvedba socialistične ureditve in je trajala do konca drugega tisočletja). Po podobni poti je šel tudi Irak (1969 do osemdesetih). Te države so izvedle nekatere ukrepe, kot so podržavljanje naftnih črpališč in industrije, forsiranje industrije kot ključnega razvojnega dejavnika, izvajali megalomanske projekte za potrebe oskrbe z vodo in povečanja prehranske neodvisnosti. Veliko pozornost so namenjali tudi izobraževanju, zdravstvu in povečevanju vojaške moči. V mnogih so se javile diktature, ki so izšle iz vzpostavljenih enostrankarskih sistemov. Gospodarsko niso bile uspešne, izolacija je krnila razvojne možnosti, že tako zmanjšane zaradi pogostih prevratov in spopadov.

Poskusi združevanja arabskih držav se niso obnesli. Tako sta se Egipt in Sirija leta 1958 povezala v Združeno arabsko republiko, a je zveza trajala le tri leta. Nekoliko drugačen poskus je bil povezava z nafto bogatih monarhij ob Arabskem zalivu na iniciativo Združenih arabskih emiratov, a ni bila uspešna. $V$ to kategorijo ne moremo šteti iraškega poskusa vojaške priključitve Kuvajta (1990-1991), ki ga je mednarodna skupnost pod ameriško taktirko kaznovala z vojno v akciji Puščavski vihar (Lacoste, 2009, str. 302).

Irak, ki se je po neuspešni agresiji na precej močnejši Iran vojaško in gospodarsko precej izčrpal in doživel korenit poraz tudi leta 1991 zaradi vdora v Kuvajt, je čez desetletje še enkrat postal tarča zahodnih koalicij. Odstranitev diktatorja je korenito posegla v geopolitično strukturo arabskega prostora. Ko je v letu 2011 sledil niz prevratov v arabskih državah (t.i. 'arabska pomlad') se je celoten prostor razgalil kot območje svetovne periferije, kljub rastoči demografski moči, izjemnemu naravnemu bogastvu ter izborni geografski legi. 


\section{SODOBNA GEOPOLITIČNA STRUKTURAARABSKEGA PROSTORA}

Presoja sodobnega geopolitičnega položaja arabskega prostora temelji na presoji notranjih in zunanjih dejavnikov. Ker imamo opraviti z obširnim in dokaj raznolikim območjem, se lahko pri orisu strukture omejimo le na najpomembnejše elemente. Pregled teh elementov kaže, da so to občutljive države: pomanjkanje regionalnih vodnih virov in zapleti z rabo razpoložljivih virov vnaša $\mathrm{v}$ geopolitični kontekst vrsto konfrontacij in torej priložnosti za odprte konflikte (Semmoud, 2010, str. 164). Naftno bogastvo je vir moči sorazmerno zelo omejenega števila prebivalstva, zato vpliva predvsem na izgradnjo infrastrukture. Socialne razlike so izjemno velike, kar državam izvoznicam (monarhije Arabskega polotoka) nudi priložnosti razvoja različnih servisnih dejavnosti. Toda te večidel opravljajo tuji delavci, katerih delež v vseh omenjenih državah presega četrtino skupnega števila prebivalstva.

Drugo plat medalje predstavljajo socialne spremembe znotraj arabskih družb. Arabske države so v zadnjih desetletjih doživele korenite družbene spremembe. Nagla rast števila prebivalstva, urbanizacija in večanje gostote prebivalstva v mestih, spreminjanje tradicionalne kmečko-obrtniške družbe v industrijsko in storitveno ter večji stik ljudi z zahodno civilizacijo so v domače okvire vztrajno vnašali nove vrednote. Na arabsko družbo so te spremembe vplivale močneje, kot se pogosto predvideva. Zelo verjetno je vpliv družbenih in socialnih sprememb odločno podcenjen. Število izobražencev se je močno povečalo in ponudba delovnih mest jim ni utegnila slediti. Mnogi (ne le izobraženi) so iskali svoje priložnosti na začasnem delu v Evropi, predvsem v državah severnosredozemskega loka (Španija, Francija, Italija), pa tudi v Srednji in Zahodni Evropi. Iz teh območij prihaja tudi glavnina turistov, kar je imelo dolgoročne ekonomske, kulturne in politične učinke (Held, Cummings, 2010, str. 118). Prav tako ne gre zanemariti različnih oblik poslovnega sodelovanja, zlasti v Tuniziji in Egiptu. Čezmediteransko regionalno sodelovanje je nedvomno perspektiva (Semmoud, 2010, str. 221-223).

Po drugi strani so postajale arabske družbe vse bolj gospodarsko ranljive. Ob povečanem številu prebivalstva se je državna usmeritev na uradništvo, naftno industrijo, kmetijstvo in turizem soočala z brezposelnostjo vse bolj izobražene mladine. Moderna arabska diaspora je bila pomemben dejavnik uravnoteženja socialnih stisk. Po nastopu svetovne gospodarske krize so se dohodki iz tega vira pričeli zmanjševati, kar je zaostrilo socialne stiske in morda tudi radikaliziralo že obstoječe nezadovoljstvo z domačimi političnimi elitami. V domačih diktaturah so hitro prepoznali krivca za svoj brezizhodni socialni položaj in jih v valu protestov odstranili z oblasti. Svetovni splet je bil ustrezen medij za pretok idej in tudi ad hoc mobilizacijo. V Libiji kot najbolj radikalni diktaturi je prišlo do državljanske vojne, ki se je končala s porazom vladnih sil in smrtjo dolgoletnega voditelja Gadafija (Der neue Fischer Weltalmanach 2013). V Siriji se je vnela državljanska vojna, ki močno spreminja položaj Turčije in Iraka, posredno pa lahko tudi Izraela.

Obširno območje arabskega prostora je na severu obkroženo z nizom prebivalstveno, gospodarsko in politično močnih držav ter državnih zvez. V zahodnem krilu so to predvsem države Evropske unije, ki danes predstavljajo pomembne gospodarske partnerje, predvsem pa so - kljub kulturnim nasprotjem - priljubljen cilj trajnih ali začasnih selitev. 
Predvsem po tej poti se naglo povečuje delež muslimanskega prebivalstva $\mathrm{v}$ evropskih državah. Srednji del zavzema Turčija, država, s katero imajo tesne zgodovinske vezi, a obenem skromno mero sedanjega sodelovanja. Vloga Turčije je povsem drugačna v odnosu do Sirije in Iraka in sicer zaradi kaotičnega stanja ter možnosti kurdskega nacionalnega preporoda. Tega Turčija dojema kot regionalno grožnjo tudi na svojem vzhodnem ozemlju. Iran je svetovno izolirana država, ki je že v preteklosti preprečevala povezovanje islamskega sveta pod rusko dominacijo na severu (Srednja Azija) in britansko-ameriško na jugu. Toda zaradi svoje islamske drže je lahko močan regionalni povezovalec, posebej v primeru nadaljnje ideologizacije islama. Iran je ne nazadnje jedrska sila in zato bolj (najmočnejši) regionalni tekmec kot povezovalec (Lacoste, 2009, str. 301-303). Nobena izmed naštetih sil neposredno ne predstavlja povezovalnega jedra, saj je njihova lastnost dolga državna tradicija in jezikovno-kulturna obeležja nacionalne identitete. Na jugu arabskega prostora je niz šibkih držav, ki jih podobno kot mnoge arabske označujejo nedavni ali še potekajoči konflikti in politično-teritorialno drobljenje: lastnosti, ki so vsaj v glavnih potezah podobne razmeram na Balkanu, na Kavkazu in v Srednji Aziji.

Arabski prostor v današnjih geopolitičnih razmerah nima svojega močnega jedra. Populacijsko jedro arabskega sveta je multietnični Egipt (Lacoste, 2009, str. 302), ki pa mu kaotične domače razmere ne omogočajo uveljavitve te priložnosti. Južni krak sestavljajo prebivalstveno močne države od Magreba do Egipta in Sudana, nato pa se razvejijo na severni krak (prek Palestine v Sirijo in Irak; torej prostor nekdanjega 'rodovitnega polmeseca') ter v južni krak (prek Sudana in Eritreje na Somalijo ter prek Rdečega morja v Jemen na Arabskem polotoku; Lacoste, 2009, str. 239-245). Na tem južnem robu že nastopajo elementi politično-teritorialnega drobljenja (Sudan) in poskusi integracije (Zahodna Sahara oziroma Maroko). Sudan je po odcepitvi Južnega Sudana dejansko razbremenjen, saj je bilo stanje trajne kaotičnosti neperspektivno. Glavni problemi v Sudanu sicer ostajajo in z njimi tudi konflikti (Petterson, 2003). Maroko predstavlja v tem regionalnem kontekstu določeno izjemo, ker je po ureditvi in gospodarski stabilnosti soroden jedru naftno bogatih monarhij večjega dela Arabskega polotoka s Saudovo Arabijo kot glavnim protagonistom. Med obema je država Izrael, v neposredni soseščini Sueškega prekopa in s tem vezi med azijsko-afriškim proizvodnim in surovinskim jedrom na eni ter evropsko potrošniško in kapitalsko-tehnološkim jedrom na drugi strani, obrobljen z nizom malih teritorijev - očitno posledica izjemne geopolitične dinamike v 20. in 21. st. Tu se nekdanja arabsko-izraelska polarizacija seli navznoter, na sama izraelska in od izraelskih vojaških sil obvladovana ozemlja (Lacoste, 2009, str. 315-317).

\section{SKLEP}

Najobsežnejši 'pas črepinj’ (Barnett, 2004) na svetu doživlja krize tako zaradi lastnih strukturnih sprememb kakor zaradi zunanjih pritiskov. Teh ne predstavlja le zahodna vojaška in tehnološka sila, temveč v vse večji meri konkurenca azijskih držav (Lacoste, 2009). Toda nič manj ni izpostavljena povezovalna vloga, zaradi katere je sem usmerjena pozornost sodobnih globalnih sil: ameriške, indijske in kitajske. Zato prva sem poleg gospodarske in 
politične moči usmerja tudi vojaško, medtem ko za drugi dve to ni mogoče trditi. A nič manj niso te sile prisotne in srednjeročno vplivne. Zlasti Kitajska ima zaradi ekonomske moči in tudi političnega vpliva zelo vidno mesto $\mathrm{v}$ naftni geopolitiki prostora med Levantom in Indijskim oceanom. Uveljavlja se tudi kot sila v Sudanu in v Afriki nasploh (Davis, Rouben, 2007). Veliko vprašanje je, ali je vztrajanje nekaterih starih vzorcev ameriških geopolitik (zapiranje ruske kopenske sile) že premagano. Tudi tako je mogoče razumeti ameriška strateška prizadevanja za omejevanjem ruskih vplivov na Balkanu, Kavkazu in v srednjeazijskih državah, ki predstavljajo staro logiko zapore ruskega 'osrčja' (Parker, 1997), čeprav je energetska odvisnost razvitega sveta zelo očitna (Klare, 2004). Toda na drugi strani ne gre prezreti potencialnih povezovalnih teženj islamskega sveta, spričo bojevitosti katerega se je vnela protiteroristična kampanja (Chomsky, 2003, str. 17; str. 156-170). Bojeviti islam po prepričanju mnogih predstavlja realno grožnjo (Muthuswamy, 2009). Toda po drugi strani raznolikost arabskega sveta ne obeta, da bi lahko le-ta tudi dejansko postal konkurenčen civilizacijski prostor. V evropski geopolitični perspektivi pa ima ta prostor zelo podobno vlogo kot srednjeazijsko-kaspijski: surovinsko jedro, tržišče in predvsem povezovališče.

\section{Viri in literatura}

Balakian, P., 2003. The burning Tigris. The Armenian genocide and America's response. New York, HarperCollins Publishers, 496 str.

Barnett, T. P. M., 2004. The Pentagon's new map. War and peace in the twenty-first century. New York, G. P. Putnam's Sons, 448 str.

Chomsky, N., 2003. Hegemony or survival. America's quest for global dominance. New York, Henry Holt and Company, 288 str.

Cohen, R., Middleton, J. (ur.), 1967. Comparative political systems: Studies in the politics of pre-industrial societies. Garden City, The Natural History Press, 512 str.

Davis, E. V. W., Rouben, A. (ur.), 2007. Islam, oil, and geopolitics. Central Asia after September 11. Lanham, Rowman \& Littlefield Publishers, 308 str.

Der Fischer Weltalmanach, Staatenlexikon. 2006. Frankfurt am Main, Fischer Taschenbuch Verlag, 446 str.

Der neue Fischer Weltalmanach 2012. Zahlen Daten Fakten. 2011. Frankfurt am Main, Fischer Taschenbuch Verlag, 800 str.

Der neue Fischer Weltalmanach 2013. Zahlen Daten Fakten. 2012. Frankfurt am Main,

Fischer Taschenbuch Verlag, 736 str.

Erhartič, B., 2009. Jemen. Ljubljana, Založba ZRC, 154 str.

Fraser, T. G, Mango, A., McNamara, R., 2011. The makers of modern Middle East. London, Haus Publishing, 342 str.

Halacoglu, Y., 2006. Die Armenierfrage. Klagenfurt/Celovec, Wieser Verlag, 132 str. Held, C. C., Cummings, J. T., 2011. Middle East patterns. Places, peoples and politics (5. izdaja). Boulder, Westview Press, 659 str.

Hourani, A., 1991. A history of the Arab peoples. New York, Warner Books, 551 str. Huntington, S. P., 1996. The clash of civilizations and the remaking of world order. London, Touchstone, 367 str. 
Klare, M. T, 2004. Blood and oil. The dangers and consequences of America's growing dependency on imported petroleum. New York, Henry Holt and Company, 288 str.

Kennedy, P. M., 2002. Aufstieg und Fall der großen Mächte. Ökonomischer Wandel und militärischer Konflikt von 1500 bis 2000. Frankfurt am Main, Fischer Taschenbuch Verlag, 976 str.

Kostova, S., Despotova, K., 2003. Rulers of the Ottoman empire. Sofija, Kibea, 120 str.

Lacoste, Y., 2009. Géopolitique. La longue histoire d'aujourd'hui. Paris, Larousse, 335 str.

Muthuswamy, M. S., 2009. Defeating political islam. The new cold war. New York, Prometheus Books, 287 str.

Napokoj, M., 2008. Libija. Ljubljana, Založba ZRC, 114 str.

Parker, G., 1997. Zahodna geopolitična misel v dvajsetem stoletju. Ljubljana, Fakulteta za družbene vede, 274 str.

Petterson, D., 2003. Inside Sudan. Political islam, conflict, and catastrophe. New York, Westview Press, 269 str.

Semmoud, B., 2010. Maghreb et Moyen-Orient dans la mondialisation. Paris, Armand Colin, 320 str.

Seton-Watson, H., 1980. Nacije i države. Zagreb, Globus, 465 str.

Slovenski veliki leksikon, 1. in 3. knjiga. 2007. Ljubljana, Mladinska knjiga.

The Times atlas svetovne zgodovine. 1989. Ljubljana, Cankarjeva založba in Mladinska knjiga, 379 str.

Time Almanac 2012. 2011. London, Encyclopedia Britanica, 864 str.

Van Dam, N., 2011. The struggle for power in Syria. Politics and society under Asad and the Ba'th Party (4. izdaja). London, I. B. Tauris, 272 str.

Vintar Mally, K., 2010. Maroko. Ljubljana, Založba ZRC, 96 str.

\section{ARAB SPACE INTHE GEOPOLITICAL PERSPECTIVE}

\section{Summary}

The paper is analysing the geopolitical features of Arab space. This is recognized by dominance of Arab language and Islamic religion and spreads in a large geographical area of North Africa and Arabian peninsula. Politically, the countries are members of Arab League, a transregional economic and cultural organization. The area is probably the largest 'shatter belt' in the world, known by inner- and outer conflicts and confrontations. Caused by some 'inner' (turbulent structural changes in the countries, weak economies and post-colonial political heritage) and 'outer' (the economic and military forces near or far of the Arab countries), many countries of this region are in crisis. The wave of uprisings and rebellions from Tunisia and Libya, through Egypt to societies in Arabian peninsula and to Syria, enlarged the crisis areas. Regime change is a typical process for practically all nonmonarchic countries, which were under Soviet influence for a distinct period and practiced some attempts of planned economy. Iraq, Syria and Libya, countries who used to be led by radical dictatorship, are now in destruction. 
According to structural analysis, the most of Arab countries are weak and vulnerable, despite their excellent geographical position, richness of metal ore and other minerals and oil- and natural gas reserves particularly. Most of them feel a serious lack of water. In the rich monarchies (emirates, sheikhdoms) along the Arabian (Persian) Gulf, the water supply depends for more than $60 \%$ on desalinization plants. A bit weaker are the regions in the Maghreb (except Morocco), even they built a large transregional waterworks (in fact: artificial rivers) and irrigation systems. In Egypt and Mesopotamia, the agricultural areas are overpopulated, the water polluted and the natural streams still used in upper valleys. Struggle for water might be a reality, as it is in areas around Israel. On the other hand, the social differentiation led to social crisis and emigration, mainly to Europe. In petrol-rich emirates, the migration flow is opposite and led to strong presence of non-citizen, foreign workers up to $25 \%$ and more of total population.

The most neuralgic zone of the Arab space is Palestine. Rich and militarily strong Israel in core and disputed, but very populated territories in the near surrounding are the result of decades-long Arab-Israeli constant confrontation and -from time to time - local wars and limited military actions. This is the area of so-called 'Fertile Crescent' from far to the west (encompassing Maghreb except Morocco) and from the deep south (through Nile Valley and farther to the Horn of Africa), across Golan Heights to Syria with continuation to Mesopotamian plain as well as to Yemeni Highlands in the southwest: this is a brief résumé of turbulent relations in the area of 1.3 million $\mathrm{km}^{2}$ and near 400 million of inhabitants. In whole this space, only the Saudi-Arabian core (together with oil-rich emirates) remains nonconflict and peaceful.

Finally, the analysis explains the contemporary geopolitical structure of Arab space. To the north, there are some strong countries or groups of countries: economic rich European Union (across the Mediterranean), westernized and secular Turkey, Shiite nuclear power Iran and population-rich and water-lacking Pakistan. Although they are very different by their structure, they represent a continental 'barrier' against Russian power in the north. This is still an old geopolitical perspective, seen by maritime powers in the near past. However, there are new powers on the scene: the Asian 'tigers' and two rivals: India and China. Their presence in the region is increasing, breaking the geopolitical perceptions of the past and probably make new patterns on world's geopolitical map.

(Translated by the author) 